\title{
A circulating anticoagulant inhibiting antihaemophilic globulin
}

\author{
P. H. PINKERTON, J. H. DAGG, AND FRANCES TAYLOR \\ From the University Departments of Haematology and Medicine, Western Infirmary, Glasgow
}

SYNOPSIS A circulating anticoagulant inhibiting antihaemophilic globulin (A.H.G.) is described in an otherwise healthy 70-year-old woman, and the therapeutic response to steroids is discusse $\mathbb{E}_{\text {. }}$. The nature and pathogenesis of the anticoagulant remain obscure, but its properties and behavio $\overrightarrow{\oplus p}$ do not support an autoimmune aetiology.

Circulating anticoagulants specifically active against antihaemophilic globulin (A.H.G.) are uncommon. They may appear in haemophilic patients, in parturient women, and in association with a variety of disorders, notably rheumatoid arthritis and penicillin sensitivity; rarely, such an anticoagulant develops spontaneously, without demonstrable associated disease. Reviews of the literature have been published by Margolius, Jackson, and Ratnoff (1961), Sise, Gauthier, Desforges, and Becker (1962), and Biggs and Macfarlane (1962).

We describe an inhibitor of A.H.G. in an otherwise healthy 70-year-old woman.

\section{METHODS}

Standard haematological investigations were as described by Dacie and Lewis (1963); investigations of the coagulation system were carried out by the methods of Biggs and Macfarlane (1962). Leucocyte ascorbic acid was estimated according to Denson and Bowers (1961). Precipitin reactions were performed on Ouchterlony plates (Anderson, Buchanan, Goudie, and Gray, 1962), and immunofluorescent studies by the technique of Weller and Coons (1954).

\section{CASE HISTORY}

M.M., a woman of 70 years, presented in December 1963 with extensive spontaneous bruising of the left arm, right thigh, abdomen, and breasts during the previous three weeks; a similar episode, involving only the left forearm, had occurred three months earlier. She had no other complaints and no family history suggestive of a haemorrhagic diathesis was elicited. She had never received a blood transfusion, had never been pregnant, and she denied any previous tendency to excessive bruising or bleeding following injury. Clinical examination confirmed the presence of extensive ecchymoses in the Received for publication 1 December 1964. areas described and haemarthrosis of the right knee was noted. The mucosal membranes were pale but no other abnormality was found.

INVESTIGATIONS Haemoglobin was $63 \% \quad(100 \%$ g 14.6 g.), P.C.V. $30 \%$, M.C.H.C. $31 \%$, W.B.C. $3,000 /$ c.mm., platelets, 210,000/c.mm., reticulocytes, $17 \%$; the film showed normochromic, normocytic red cells wi some polychromasia, a slight neutropenia, and plentifi্d platelets of normal appearance. The bone marrow wfss hypercellular with stainable iron absent; erythropoies.js was hyperplastic and normoblastic and plasma cells were present in normal numbers.

The Coombs test, the L.E. cell test and the latex L.尹. test were negative; Heinz bodies were absent; serum albumin and globulin concentrations were normal with a normal electrophoretic pattern, and macroglobulins amd cryoglobulins could not be demonstrated. Serum iron was $30 / \mu \mathrm{g} . / 100 \mathrm{ml}$., I.B.C.,T. $295 / \mu \mathrm{g} . / 100 \mathrm{ml}$,, leucocyse ascorbic acid, $26 \mu \mathrm{g}$. per $10^{8}$ white cells (normal range, 23-53 $\mu$ g. per $10^{8}$ white cells). Estimation of blood urea and serum electrolyte concentrations and liver function tests, including bromsulphthalein excretion, gave resufs in the normal range. The Wassermann reaction was negative and a chest radiograph and barium mal examination revealed no abnormality.

INVESTIGATION OF THE HAEMOSTATIC MECHANISMS THPe tourniquet test was negative; the bleeding time was min. (normal, less than 7 min.); clotting time, 55 min. (normal, 5-11 min.); clot retraction, normal; fibrinogen, $270 \mathrm{mg}$. per $100 \mathrm{ml}$; thrombin clotting time, $8 \mathrm{~s}$. (control, $8 \mathrm{sec}$.); antithrombin assay, $120 \mathrm{u} . / \mathrm{ml}$. (cont $100 \mathrm{u} . / \mathrm{ml}$.); one-stage prothrombin time, $13.5 \mathrm{sec}$. (control $13.5 \mathrm{sec}$.); two-stage prothrombin time $98 \%$; prothronbin consumption index, $140 \%$ (normal, less than $40 \%$ ), Thrombotest (Owren) showed $100 \%$ of normal coagu tion activity.

The recalcification time was $900 \mathrm{sec}$. (normal contôl $105 \mathrm{sec}$.), and the recalcification time of a mixturefof equal parts of normal and patient's plasma was $345 \mathrm{sec}$. 
No correction was obtained by the addition of protamine in amounts of $0 \cdot 5,2 \cdot 0$, and $5.0 \mathrm{mg}$. per $\mathrm{ml}$.

The results of the thromboplastin generation test are presented in Table I and show a defect in the patient's absorbed plasma, a defect which was not demonstrated in the patient's serum.

The thromboplastin generation test was modified to include various combinations of normal, haemophilic and patient's plasma, and patient's serum. The results are shown in Table II. The addition of patient's plasma at saline dilutions of either 1 in 5 or 1 in 10 in an otherwise normal generating system produced impairment of thromboplastin formation, whereas incorporation of patient's serum produced only minimal alterations. Mutual correction of the defect was not produced when a mixture of patient's and haemophilic plasma was used.

When patient's plasma was used as substrate in the thromboplastin generation test with a normal generation mixture, a normal result was obtained (Table III), demonstrating that there was no inhibition of formed thromboplastin. Inhibition of human brain thromboplastin (tissue factor) was not present (Table IV).

Christmas factor assays on the patient's plasma and on a mixture of 7 parts of normal plasma to 3 parts of patient's plasma after one hour's incubation at $37^{\circ} \mathrm{C}$. gave normal results (Dr. A. S. Douglas).

Assays of A.H.G. in the patient's plasma revealed no demonstrable A.H.G. activity and when 1 part of the
TABLE IV

CLOTTING TIMES WITH INCREASING DILUTIONS OF BRAIN THROMBOPLASTIN

Dilutions of Brain Thromboplastin

\begin{tabular}{llllll}
\cline { 2 - 5 } Plasma & $1 / 10$ & $1 / 100$ & $1 / 1,000$ & $1 / 10,000$ & Nil \\
\hline Normal & $18 \mathrm{sec}$. & $31 \mathrm{sec}$. & $66 \mathrm{sec}$. & $95 \mathrm{sec}$. & $180 \mathrm{sec}$. \\
Patient & $18 \mathrm{sec}$. & $30 \mathrm{sec}$. & $60 \mathrm{sec}$. & $95 \mathrm{sec}$. & $420 \mathrm{sec}$.
\end{tabular}

patient's plasma was mixed with 4 parts of normal plasma (A.H.G. concentration $100 \%$ ) and assayed immediately, the A.H.G. concentration in the mixture fell to $12 \%$, confirming the presence of specific inhibitor of A.H.G. Increase in this degree of inhibition was not produced by incubation of a similar mixture of normal and the patient's plasma for one hour at $37^{\circ} \mathrm{C}$.

An A.H.G. assay was performed on mixtures of normal plasma (100\% A.H.G.) 1 part, with patient's serum, 1 part, before and after absorption of serum with alumina (Biggs and Macfarlane, 1962); inhibition of A.H.G. could not be demonstrated.

Studies of factors XI and XII were not carried out and the presence of inhibitors of these factors in addition to the inhibition of A.H.G. cannot be excluded.

IMMUNOLOGICAL STUDIES The patient's serum and plasma were set up in Ouchterlony plates against reconstituted lyophilized Cohn's fraction I, at dilutions varying

TABLE I

RESULTS OF THROMBOPLASTIN GENERATION TESTS

Generation Mixture

\begin{tabular}{|c|c|c|c|c|c|c|c|c|}
\hline Platelets & $\begin{array}{l}\text { Absorbed } \\
\text { Plasma. }\end{array}$ & Serum & 1 Min. & $2 M i n$ & 3 Min. & 4 Min. & 5 Min. & 6 Min. \\
\hline $\begin{array}{l}\text { Normal } \\
\text { Normal } \\
\text { Normal } \\
\text { Normal }\end{array}$ & $\begin{array}{l}\text { Normal } \\
\text { Patient } \\
\text { Patient } \\
\text { Normal }\end{array}$ & $\begin{array}{l}\text { Normal } \\
\text { Patient } \\
\text { Normal } \\
\text { Patient }\end{array}$ & $\begin{array}{l}60 \\
60+ \\
60+ \\
60+\end{array}$ & $\begin{array}{l}47 \\
60 \\
60 \\
50\end{array}$ & $\begin{array}{l}25 \\
60 \\
57 \\
30\end{array}$ & $\begin{array}{l}15 \\
60 \\
57 \\
16\end{array}$ & $\begin{array}{l}11 \\
55 \\
50 \\
14\end{array}$ & $\begin{array}{l}10 \\
50 \\
50 \\
12\end{array}$ \\
\hline
\end{tabular}

TABLE II

RESULTS OF THROMBOPLASTIN GENERATION TESTS ${ }^{1}$

Generation Mixture

\begin{tabular}{|c|c|c|c|c|c|c|c|c|c|c|}
\hline $\begin{array}{l}\text { Normal } \\
\text { Plasma }\end{array}$ & $\begin{array}{l}\text { Patient's } \\
\text { Plasma }\end{array}$ & $\begin{array}{l}\text { Haemophilic } \\
\text { Plasma }\end{array}$ & Saline & $\begin{array}{l}\text { Patient's } \\
\text { Serum }\end{array}$ & I Min. & 2 Min. & 3 Min. & 4 Min. & 5 Min. & $6 \mathrm{Min}$. \\
\hline $\begin{array}{l}1 / 5 \\
1 / 5 \\
1 / 5 \\
1 / 5 \\
-1 / 5\end{array}$ & $\begin{array}{l}\overline{1 / 5} \\
1 / 10 \\
\overline{1 / 5} \\
-\end{array}$ & $\begin{array}{l}- \\
- \\
\overline{1} / 5 \\
1 / 5 \\
-\end{array}$ & $\begin{array}{l}+ \\
- \\
- \\
- \\
-\end{array}$ & $\begin{array}{l}- \\
- \\
- \\
\overline{1} \\
1 / 5\end{array}$ & $\begin{array}{l}49 \\
60 \\
59 \\
60 \\
60+ \\
60\end{array}$ & $\begin{array}{l}30 \\
50 \\
50 \\
50 \\
60+ \\
30\end{array}$ & $\begin{array}{l}21 \\
40 \\
40 \\
24 \\
60+ \\
19\end{array}$ & $\begin{array}{l}12 \\
28 \\
25 \\
19 \\
60+ \\
17\end{array}$ & $\begin{array}{l}12 \\
17 \\
16 \\
19 \\
60+ \\
16\end{array}$ & $\begin{array}{l}11 \\
17 \\
16 \\
18 \\
60+ \\
16\end{array}$ \\
\hline
\end{tabular}

Each generation tube contained $0.2 \mathrm{ml}$. of normal serum (1/10) and $0.2 \mathrm{ml}$. normal platelet suspension in addition to the above.

\section{TABLE III}

RESULTS OF THROMBOPLASTIN GENERATION TESTS

Clotting Times (sec.) in Subsampling Tubes after

\begin{tabular}{llllll} 
Generation Mixture Normal & 1 Min. & 2 Min. & 3 Min. & 4 Min. & 5 Min. \\
\hline Substrate plasma, normal & 60 & 20 & 15 & 13 & 12 \\
Substrate plasma, patients & 54 & 25 & 15 & 11 & 12
\end{tabular}


from 1 in 1 to 1 in 8. Precipitation lines were not demonstrated.

Reconstituted Cohn's fraction I was labelled with ${ }^{131}$ iodine and mixed with a normal and the patient's plasma in proportions of 1 part of Cohn's fraction I to 5 parts of plasma. The mixtures were then electrophoresed for three hours at 130 volts and $0.4 \mathrm{ma} / \mathrm{cm}$. on cellulose acetate strips (Oxoid). Half of each strip, cut longitudinally, was stained with bromophenol blue; there was no difference in the electrophoretic pattern between the two strips. Autoradiography was performed on the other half of each strip and no alteration in the migration of the labelled Cohn's fraction I could be demonstrated. Thus there was no evidence that the patient's plasma combined with a constituent of Cohn's fraction I to produce an alteration in electrophoretic pattern.

Fractionation of the patient's plasma with $18 \%$ sodium sulphate was carried out and the supernatant and redissolved precipitate were incorporated separately in an A.H.G. assay system. The supernatant lacking in $\gamma$ globulin (Fig. 1), produced inhibition of A.H.G. but the redissolved precipitate did not, demonstrating that the circulating anticoagulant was not a $\gamma$ globulin. The supernatant was not dialysed to remove sodium sulphate, but the addition of $18 \%$ sodium sulphate to an assay system did not result in inhibition of A.H.G.

Using immunofluorescent methods, the presence of antinuclear factor and antibodies to gastric mucosa could not be demonstrated but moderately strong fluorescence was obtained with thyroid, indicating the presence of antibody to the thyroid epithelial 'microsomal' antigen; the tanned red cell agglutination test for antithyroglobulin (Anderson, 1964) was negative. The RoseWaaler test was negative.

PROPERTIES The inhibitor of A.H.G. is stable at

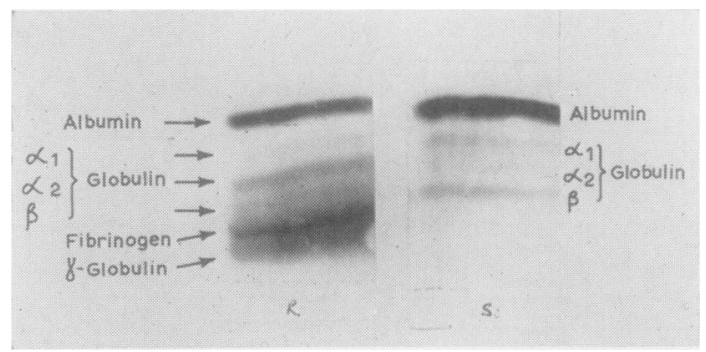

FIG. 1. Electrophoretic strip of the redissolved precipitate $(R)$ and the supernatant $(S)$ following fractionation with $18 \%$ sodium sulphate. $-20^{\circ} \mathrm{C}$. for six months, and at $56^{\circ} \mathrm{C}$. for $40 \mathrm{~min}$. (Tabe $\mathrm{V})$, but is destroyed by heating to $100^{\circ} \mathrm{C}$. for $5 \mathrm{~min}$. is absent from serum and is not a $\gamma$ globulin.

TREATMENT AND PROGRESS The haemoglobin rose quickly with oral iron therapy and spontaneous bruisin ceased following admission. The mild neutropenis which remains unexplained, proved transient, and the elevated reticulocyte count, which fell rapidly as the haemoglobin concentration rose, was regarded as resactive to blood loss.

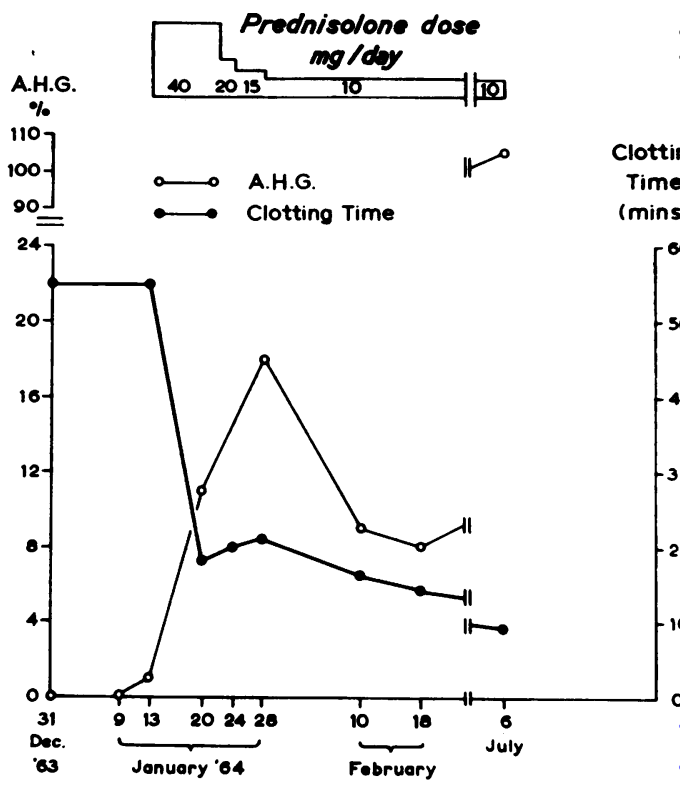

FIG. 2. Changes in clotting time and A.H.G. concer tration during prednisolone therapy.

A course of prednisolone, begun nine days aftex admission, coincided with a rapid fall in the whole bloog clotting time and rise in A.H.G. concentration to $18^{\circ}$ However, following a reduction in steroid dosage $10 \mathrm{mg}$. daily the level of A.H.G. fell to $8-9 \%$ (Fig. $2 \frac{\mathrm{K}}{\mathrm{C}}$

Antihaemophilic globulin assays performed on mixos tures of 3 parts of patient's plasma and 7 parts of normab plasma (A.H.G. $100 \%$ ) after 19 and 32 days' sterof therapy gave results of $80 \%$ and $75 \%$ respectivel indicating the disappearance of inhibitor activits

TABLE V

THROMBOPLASTIN GENERATION TESTS

Clotting Time (sec.) of Substrate Tubes after

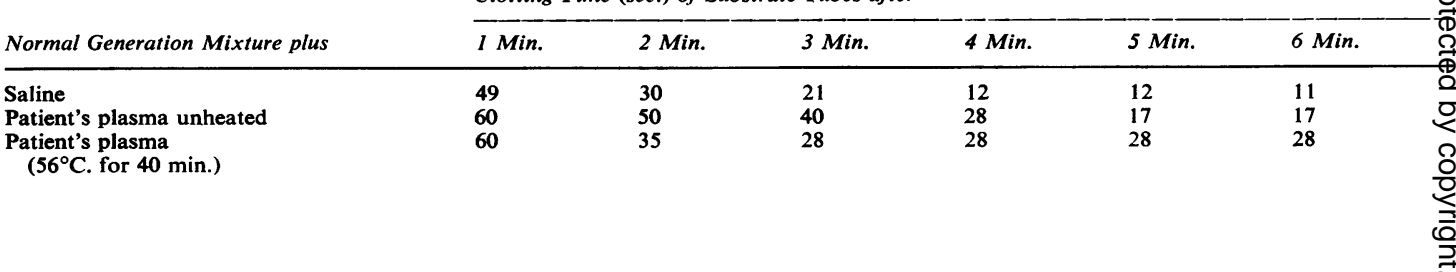


although the A.H.G. concentration in the patient's plasma remained low (Fig. 2). These assays were performed without prior incubation at $37^{\circ} \mathrm{C}$. as it had been previously established that this did not increase the degree of inhibition.

A maintenance dose of $10 \mathrm{mg}$. of prednisolone daily was continued, and six months later the A.H.G. concentration was $105 \%$ with a whole blood clotting time of $9 \mathrm{~min}$.

\section{DISCUSSION}

Circulating anticoagulants inhibiting A.H.G. have been observed in four groups of patients. In classical haemophiliacs (Craddock and Lawrence, 1947; Lawrence and Craddock, 1947; Frommeyer, Epstein, and Taylor, 1950; Hougie and Fearnley, 1954; Lewis, Ferguson, and Arends, 1956; Verstraete and Vandenbroucke, 1956; Biggs and Bidwell, 1959; Margolius et.al., 1961); in women who developed a haemophilia-like condition in association with pregnancy and parturition (Bruno and Brody, 1954; O'Brien, 1954; Nilsson, Skanse, and Gydell, 1958; Margolius et al., 1961; Walpot, 1964); in association with a variety of disorders, e.g., rheumatoid arthritis (Collins and Ferriman, 1952; Spaet and Kinsell, 1954; Favre-Gilly, Thouverez, and TourniaireLamicq, 1958; Margolius et al., 1961; Lee and Raccuglia, 1962; Sise et al., 1962), rheumatic heart disease (Hardisty, 1954), penicillin sensitivity (Nussey and Dawson, 1957; Margolius et al., 1961), rheumatic fever with idiopathic thrombocytopenic purpura (Barkhan 1952), hyperglobulinaemia (Nilsson and Wenckert, 1953), regional enteritis (Ellis, Handley, and Taylor, 1959), 'collagen disease' (Margolius et al., 1961), and syphilis with tuberculous lymphadenopathy (Lozner, Jolliffe, and Taylor, 1940); and unassociated with any demonstrable underlying disease or condition (Collins, 1953; Hougie, 1953; Goldstein, 1954; Evans, 1955; Lewis et al., 1956; Verstraete and Vandenbroucke 1956; Biggs and Bidwell, 1959; Henderson, 1959; Margolius et al., 1961; Breckenridge and Ratnoff, 1962; Ehrenworth, 1963).

The case reported here appears to fall into the fourth or 'idiopathic' group although the anticoagulant differs in some respects from those previously described.

The anticoagulants formed in these various groups of subjects cannot be distinguished from one another by their physical or chemical characteristics. Where biochemical characterization has been carried out, the anticoagulant in previous cases has been a globulin and in many instances has been localized to the $\gamma$ globulin fraction. The view has been repeatedly expressed that the anticoagulant in these cases is of the nature of an antibody, and positive precipitin reactions have been reported by several authors in the haemophilic group (Craddock and Lawrence, 1947; Frommeyer et al., 1950; Hougie and Fearnley, 1954; Verstraete and Vandenbroucke, 1956) and in the idiopathic group (Hougie, 1953; Verstraete and Vandenbroucke, 1956); other authors have reported negative precipitin reactions in cases from all four groups (Conley, Ratnoff, Ellicott, and Hartmann, 1950; Hardisty, 1954; Biggs and Bidwell, 1959; Breckenridge and Ratnoff, 1962).

The association of circulating anticoagulants of this type with the various disorders of the immunological mechanisms in the third group has been invoked as further support for the theory that these anticoagulants represent an immune phenomenon (Collins and Ferriman, 1952; Spaet and Kinsell, 1954; Nussey and Dawson, 1957; Favre-Gilly et al., 1958).

However, Biggs and Bidwell (1959) were unable to demonstrate antibody-like activity to A.H.G. in the plasma or serum of patients in the haemophilic and idiopathic groups, using tanned red cell and Coombs inhibition techniques. They also considered that the increase in inhibitory activity over quite long periods of time of exposure of A.H.G. to inhibitor in their cases would suggest that the reaction is not antigen-antibody in type. Breckenridge and Ratnoff (1962) suggested that in their case, one of the 'idiopathic' variety, the inhibitor was enzymatic in nature.

In most of the previous cases where activity has been sought in the serum it has been clearly present, and, indeed, Hougie and Fearnley's (1954) test for 'antithromboplastinogens' depends on this.

In the present case, the inhibitor is not a $\gamma$ globulin and it has not been possible, by the techniques employed, to demonstrate antibody activity to A.H.G. in the patient's plasma.

Apart from antibody to thyroid tissue, no evidence of an autoimmune disorder has been discovered; the presence of this antibody is of doubtful significance as antithyroid antibodies can be demonstrated in $16.8 \%$ of apparently normal females over the age of 50 years (Goudie, Anderson, and Gray, 1959).

Although the rapid inhibition of A.H.G. by the patient's plasma in the assay system is consistent with an antigen-antibody type of reaction, our findings in general do not lend support to the suggestion that these circulating anticoagulants represent an immune phenomenon. Nor do they support the theory of an enzymatic action of inhibitor, for activity is absent from serum, i.e., it is consumed or destroyed during coagulation, and is not increased by incubation with 'substrate.'

The effect of steroid therapy in subjects with inhibitors of A.H.G. is variable, some responding 
well, some poorly, and some not at all. The value of this therapy is hard to assess as the possibility of coincidental spontaneous remission cannot be excluded. A good response to therapy in the idiopathic group is unusual, occurring in only one (Evans, 1955, case II) out of seven cases so treated. In the patient studied here clinical improvement preceded steroid therapy in that spontaneous bruising ceased. However, improvement of the coagulation state in vitro coincided with the commencement of steroid therapy and a decrease in the patient's A.H.G. concentration followed a decrease in steroid dosage. After six months' therapy, the A.H.G. concentration and whole blood clotting time were normal. The evidence would thus seem to point to a beneficial effect of steroids and this favourable response, and that obtained by Evans (1955) in case II, should encourage the trial of steroids.

The apparent suppression of the anticoagulant by steroid therapy is in keeping with an autoimmune phenomenon, but cannot be taken as proof of this mechanism. Indeed, the nature and pathogenesis of the inhibitor of A.H.G. in this patient remains obscure.

We are grateful to Sir Edward Wayne and to Dr. A. Goldberg for permission to publish this case, and to Dr. J. R. Anderson and Dr. A. S. Douglas for advice and assistance with the immunological investigations, and the investigation of the coagulation defect. We are indebted to Miss Morna Gale and Mrs. Patricia Waters for technical assistance.

\section{REFERENCES}

Anderson, J. R. (1964). Recent Advances in Clinical Pathology, Series $I V$, p. 364. Churchill, London.
Buchanan, W. W., Goudie, R. B., and Gray, K. G. (1962) J. clin. Path., 15, 462.

Barkhan, P. (1952). S. Afr. J. med. Sci., 17, 87.

Biggs, R., and Bidwell, E. (1959). Brit. J. Haemat., 5, 379. and Macfarlane, R. G. (1962). Human Blood Coagulation, $3 \mathrm{r}$ ed. Blackwell, Oxford.

Breckenridge, R. T., and Ratnoff, O. D. (1962). Blood, 20, 137

Bruno, M. S., and Brody, H. S. (1954). Amer.J. Med., 16, 756.

Collins, I. S. (1953). Aust. Ann. Med., 2, 161.

- , and Ferriman, D. G. (1952). Lancet, 2, 712.

Conley, C. L., Ratnoff, O. D., Ellicott, C. E., and Hartmann, R. C. (1950). J. clin. Invest., $29,1182$.

Craddock, C. G. Jr., and Lawrence, J. S. (1947). Blood, 2, 505.

Dacie, J. V., and Lewis, S. M. (1963). Practical Haematology, 3rd ed $\overrightarrow{0}$ Churchill, London.

Denson, K. W., and Bowers, E. F. (1961). Clin. Sci., 21, 157.

Ehrenworth, L. (1963). Amer. J. Med., 34, 272.

Ellis, H., Handley, D. A., and Taylor, K. B. (1959). Lancet, 1, 116

Evans, D. M. D. (1955). J. clin. Path., 8, 168.

Favre-Gilly, J., Thouverez, J. P., and Tourniaire-Lamicq, M. (1958) Sang, 29, 517.

Frommeyer, W. B. Jr., Epstein, R. D., and Taylor, F. H. L. (1950) Blood, $5,401$.

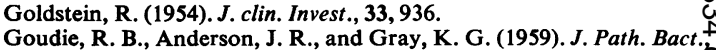
77, 389.

Hardisty, R. M. (1954). J. clin. Path., 7, 26.

Henderson, W. M. R. (1959). Brit. med.J., 1, 764.

Hougie, C. (1953). J. clin. Path., 6, 30.

- and Fearnley, M. E. (1954). Acta haemat. (Basel), 12, 1

Lawrence, J. S., and Craddock, C. G. Jr. (1947). Science, 106, 473.

Lee, M. L., and Raccuglia, G. (1962). Ann. intern. Med., 56, 946.

Lewis, J. H., Ferguson, J. H., and Arends, T. (1956). Blood, 11, $846 \%$

Lozner, E. L., Jolliffe, L. S., and Taylor, F. H. L. (1940). Amer. J: med. Sci., 199, 318.

Margolius, A. Jr., Jackson, D. P., and Ratnoff, O. D. (1961). Medicine (Baltimore), 40, 145.

Nilsson, I. M., Skanse, B., and Gydell, K. (1958). Acta haemat. (Basel) $19,40$.

- , and Wenckert, A. (1953). Blood, 8, 1067.

Nussey, A. M., and Dawson, D. W. (1957). Brit. med. J., 2, 1077.

O'Brien, J. R. (1954). J. clin. Path., 7, 22.

Sise, H. S., Gauthier, J., Desforges, J., and Becker, R. (1962). Amero J. Med., 32, 964.

Spaet, T. H., and Kinsell, B. G. (1954). Stanf. med. Bull., 12, 246.

Verstraete, M., and Vandenbroucke, J. (1956). J. Lab. clin. Med., 48 673.

Walpot, L. (1964). Ned. T. Geneesk., 108, 127.

Weller, T. H., and Coons, A. H. (1954). Proc. Soc. exp. Biol. (N.Y.) 86, 789. 